\title{
Features of Designing Water Reservoirs in the Conditions of the North
}

\author{
Anatoly I. Matiushenko* and Gregory V. Krasavin \\ Siberian Federal University \\ 79 Svobodny, Krasnoyarsk, 660041, Russia
}

Received 21.03.2017, received in revised form 06.06.2017, accepted 13.12.2017

Some features of design of water intake facilities in Siberia from underground and surface sources are outlined. The accumulated experience in design and construction on permafrost at present allows creating reliable and economical water supply systems for objects of any purpose in various permafrost-climatic conditions.

Keywords: design and calculation of water intakes, coefficient of roughness, underground and surface sources.

Citation: Matiushenko A.I., Krasavin G.V. Features of designing water reservoirs in the conditions of the north, J. Sib. Fed. Univ. Eng. technol., 2018, 11(1), 116-122. DOI: 10.17516/1999-494X-2018-11-1-000-000.

\section{Особенности проектирования водозаборов в условиях Севера}

\author{
А.И. Матюшенко, Г.В. Красавин \\ Сибирский федеральный университет \\ Россия, 660041, Красноярск, пр. Свободный, 79
}

Изложены некоторые особенности проектирования водозаборных сооружений в Сибири из подземных и поверхностных источников. Накопленный опыт проектирования и строительства на мерзлоте в настоящее время позволяет создавать надежные и экономичные системы водоснабжения для объектов любого назначения в различных мерзлотно-климатических условиях.

Ключевые слова: проектирование и расчет водозаборов, коэффициент шероховатости, подземные и поверхностные источники.

Водоснабжение на Севере имеет свои особенности. В условиях Севера значительно усложняются проблемы, решаемые при проектировании, ведении изысканий, строительстве и экс-

(C) Siberian Federal University. All rights reserved

* Corresponding author E-mail address: matyshenko@icoud.com 
плуатации водопроводных сооружений. При проектировании систем водоснабжения необходимо учитывать исключительное значение надежного водообеспечения. Суровый климат Севера и вечная мерзлота требуют их учета при проектировании [1-7].

Низкие отрицательные температуры среды создают постоянную угрозу замерзания воды на любом участке от источника до потребителя. Низкие температуры и мерзлота сильно влияют на планирование, проектирование, строительство и эксплуатацию системы водоснабжения. Это проявляется в удорожании водоснабжения, усложнении устройств и сооружений, существенном удорожании их эксплуатации $[8,9]$. Кроме того, на Севере, более чем в других районах, важно правильно оценить геокриологические свойства и особенности грунтов с прогнозом их изменения в зависимости от принятого принципа строительства сооружений.

На Севере проявляются специфические особенности прокладки трубопроводов, вызванных мерзлотно-грунтовыми и климатическими условиями районов, где происходит глубокое сезонное промерзание грунтов [10-12].

Схемы водоснабжения на Севере изменяются в больших пределах в зависимости от мерзлотно-климатических условий и технико-экономических соображений [13]. Основополагающим является водоисточник, его расположение относительно потребителя. Мощность и режим водоисточников определяют не только схему водоснабжения, но и конструкции всех сооружений, условия строительства и эксплуатации.

Источниками водоснабжения на Севере служат поверхностные воды (реки, озера, пруды, водохранилища), подземные воды (надмерзлотные, межмерзлотные, подмерзлотные), а также снег и лед наледей, подземных линз, ледников, специальных льдозапасов. Возможности использования поверхностных источников определяются их мощностью, мерзлотногидрологическими характеристиками, а также возможностью их перемерзания.

Наиболее реальными и доступными для большинства объектов на Севере являются поверхностные воды. Отличительной особенностью гидрографа большинства рек Ледовитого бассейна слжит исключительная неравномерность внутригодового распределения стока, большие расходы в паводки сопровождаются бурными ледоходами и разливами. Зимний сток даже крупных рек незначителен.

Использование поверхностных источников для водоснабжения существенно зависит от особенностей шуголедового и гидротермического режимов водотока. Ледоходы на Севере отличаются мощностью, длительностью и заторами. Возникающие ледяные заторы и их подвижки при подъемах уровней, навалы на берегах мощных глыб льда часто исключают возможность строительства любых гидросооружений, выступающих в русло [4, 5].

Водозаборные сооружения служат для забора воды из водоисточника и подачи ее под необходимым напором в сеть или на очистные сооружения. Успешная работа системы водоснабжения в большой степени зависит от бесперебойной работы водозабора, соответствующей производительности. Подача воды в водопровод требуемого количества и качества должна быть гарантирована при всех расходах и уровнях в реке и при самых неблагоприятных возможных сочетаниях гидрологических, гидравлических, термоледовых и других условий.

По месту расположения водоприемника поверхностные водозаборы бывают:

- берегового типа, у которых водоприемники располагаются на берегу, а его водоприемные отверстия всегда доступны для обслуживания; 
- руслового типа, водоприемники которых затоплены и удалены от берега, а их водоприемные отверстия в отдельные периоды года (шугоход) оказываются практически недоступными.

Русловые водозаборы состоят из оголовка, самотечно-сифонных трубопроводов и берегового колодца, зачастую объединенного с насосной станцией I подъема.

Водозаборы берегового типа возводятся на крутых берегах рек или насыпных площадках, где имеются условиях обеспечивающие подачу воды в водоприемные окна при любом уровне в реке.

Доступность водоприемных отверстий для обслуживания имеет большое значение для бесперебойной подачи воды. Поэтому береговые водозаборы по надежности подачи воды оцениваются одной категорией выше.

При выборе места водозабора для районов распространения многолетнемерзлых грунтов необходимо учитывать: степень промерзания водоемов, наличие талых подрусловых зон грунтов, температуры воды в водоисточнике в зимний период, влияние оттаивающих грунтов на качество забираемой воды, возможность расположения водозабора вблизи источника тепла (ТЭЦ, котельные и т.п.).

Водоприемник хозяйственно-питьевого водозабора должен быть расположен в месте, удовлетворяющем санитарным требованиям, т.е. выше населенных мест, там, где есть возможность организовать необходимые зоны санитарной охраны. Водозаборные сооружения должны быть простыми, удобными в эксплуатации, надежными, прочными и долговечными. При проектировании русловых водоприемных оголовков надо учитывать данные о ледовом режиме, толщине льда, продолжительности ледохода, о шуге, заторах, образовании торосов и другие факторы, влияющие на выбор конструкции оголовка. В большинстве случаев оголовки доставляют к месту установки в готовом виде.

Оголовок должен находиться на такой глубине, чтобы водоприемное отверстие нижним краем возвышалось над дном реки на 0,5-0,7 м. Расстояние верхнего края водоприемного отверстия от нижней поверхности ледяного покрова должно быть не менее $0,2-0,3$ м. Дно реки около оголовка укрепляется каменной наброской для предотвращения размыва дна.

От попадания рыбы и предметов средней величины оголовки ограждают решетками и рыбозащитными кассетами. Главное средство защиты от шуги состоит в уменьшении входной скорости воды до 0,05-0,04 м/с. Стержни решеток должны быть изготовлены из гидрофобных материалов или покрыты ими.

Повышение надежности руслового водозабора осуществляется за счет производства промывки водоприемных окон (фильтров) обратным током воды, импульсами давлений. Импульсная промывка оголовка достигается установкой специальной колонны с вакуум-насосами. Столб воды в колонне при срыве вакуума возбуждает колебания масс воды и обеспечивает промывку водоприемника.

Береговые колодцы руслового водозабора необходимо располагать как можно ближе к водоему, чтобы уменьшить длину самотечных трубопроводов. Совмещение насосной станции I подъема с водоприемным колодцем снижает стоимость сооружения и уменьшает длину всасывающих труб. 
Чтобы избежать изменений русла реки, водоприемники должны возможно меньше нарушать ее естественный режим и нужно принимать меры по закреплению русла в той форме, какая необходима для работы водозабора.

Большие перепады уровней воды в реке и ограниченная высота всасывания насосов заставляют заглублять на берегу водоприемники и насосные станции І подъема.

Примером водозабора руслового типа является хозпитьевой водозабор г. Игарки.

Для решения вопросов хозпитьевого водоснабжения г. Игарки в 2011 г. была разработана проектная документация на строительство сооружений внеплощадочного водоснабжения г. Игарки с реконструкцией водозаборных сооружений. Расчетная производительность $4200 \mathrm{~m}^{3} /$ сут.

Строительство запроектированных сооружений завершено в текущем году.

Существующие водозаборные сооружения из р. Енисей располагаются на правом берегу протоки Игарской, были построены в 1968 г. для водоснабжения Игарского ЛПК и старой застройки города.

Состав реконструируемого водозабора:

- русловой затопленный оголовок с фильтрующими кассетами;

- самотечно-сифонные водоводы;

- водоприемный колодец, совмещенный с насосной станцией I подъема;

- берегоукрепление;

- напорные водоводы до очистных сооружений;

- зона санитарной охраны I пояса.

Проектом реконструкции предусматривается новый русловый водоприемный оголовок раструбного типа с прокладкой от него двух самотечно-сифонных линий из стальных труб диаметром 325 мм до водоприемной камеры береговой насосной станции (кессона).

Раструбный оголовок на железобетонной плите состоит из двух секций. Каждая секция оборудуется съемной фильтрующей рыбозащитной кассетой, совмещенной с сороудерживающей решеткой. Для защиты оголовка от ударов плывущего льда вокруг оголовка предусматривается устройство ледозащитных свай.

Укладка участка подводных трубопроводов от оголовка планировалась в открытой траншее методом свободного погружения.

Амплитуда колебания уровней воды в реке в створе водозабора составляет 22 м, максимальная толщина льда 1,57 м, продолжительность ледостава 220 дней.

Существующая насосная станция I подъема сблокирована с 2-секционным водоприемником. Подземная часть диаметром 10 м представляет собой железобетонный колодец - кессон глубиной 27,7 м. В насосной станции произведена замена технологического оборудования, в машзале устанавливаются основные насосы фирмы «GRUNDFOS», зарядка сифонных водоводов при низких уровнях воды в реке производится вакуумной установкой с насосами ВBН11,5 .

Основные технологические процессы автоматизируются. Насосная станция запроектирована без постоянного обслуживающего персонала. Контроль и управление работой узла осуществляется с диспетчерского пункта на станции очистки воды.

Реконструируемые водозаборные сооружения сданы в эксплуатацию в сентябре 2017 г. 


\section{Подземные воды}

Использование подземных вод в криолитозоне очень затруднено, так как возможно замерзание воды в стволах скважин. Количество потребителей, снабжаемых подмерзлотными водами, на Севере невелико из-за сложности защиты скважин от перемерзания, высокой стоимости бурения скважин и водоподготовки при высокой минерализации подземных вод $[3,6-8]$.

Для организации централизованного хозяйственно-питьевого водоснабжения перевалочной базы «Прилуки» в качестве источника водоснабжения приняты подмерзлотные воды - водоносного комплекса коренных пород. Площадки проектируемых сооружений расположены в Туруханском районе Красноярского края на левом берегу р. Енисей в 3,7 км западнее г. Игарки. Район работ расположен в области распространения многолетнемерзлых пород с наличием надмерзлотных и сквозных таликов. Многолетнемерзлые грунты находятся в пластичномерзлом состоянии. Глубина сезонного оттаивания грунтов колеблется от 0,7 до $1,5 \mathrm{M}$.

Использование в качестве источника водоснабжения поверхностных вод р. Енисей требует значительно больших затрат на строительство открытого водозабора из реки с амплитудой колебания уровней 22 м, с тяжелыми шуголедовыми условиями, а также необходимостью очистки воды на очистных сооружениях. При наличии в районе проектируемого объекта подземных вод для организации хозяйственно-питьевого водоснабжения отдается предпочтение подземным водам.

Проектируемые водозаборные сооружения производительностью 600 м³/сут приняты в составе трех водозаборных скважин (две рабочих, одна резервная). Глубина скважин 122 м. Скважины оборудуются погружными насосами типа SP17-9 фирмы «GRUNDFOS». Работа насосов автоматизируется от уровня воды на площадке резервуаров.

Для предотвращения замерзания воды в стволах скважин (при длительных перерывах откачки) предусматривается обогрев скважин греющим электрокабелем. Греющий кабель опускается в скважину на 2-3 м ниже подошвы мерзлоты и работает периодически или постоянно. Этот метод защищает скважины, работающие в любом режиме, при любых колебаниях уровней от перемерзания, позволяет восстанавливать перемерзшие скважины. Над скважинами предусматриваются наземные павильоны насосных станций размером 3х4 м.

При проектировании насосных станций на скважинах №№ $1 \div 3$ применен принцип строительства на вечномерзлых грунтах с устройством холодного подполья, при котором вечномерзлые грунты используются в мерзлом состоянии, сохраняемом в процессе строительства и в течение всего периода эксплуатации. Высота холодного подполья 1,15 м. Фундаменты насосных станций производят из металлических свай, погружаемых буроопускным способом, ростверк металлический.

Напорные водоводы от водозабора приняты из стальных труб диаметром 89х4 мм ГОСТ 8732 из стали марки 09Г2С в тепловой изоляции толщиной 100 мм, состоящей из цилиндров «ROCK WOOL» с покровным слоем из тонколистовой оцинкованной стали и зашитой от промерзания греющим кабелем, прокладываемым под слоем тепловой изоляции. Предусматривается наземная прокладка напорных водоводов. Трубы укладываются по скользящим опорам, утепленным минераловатными матами, устанавливаемым на бетонных плитах. 
Накопленный опыт проектирования и строительства на мерзлоте в настоящее время позволяет создавать надежные и экономичные системы водоснабжения для объектов любого назначения в различных мерзлотно-климатических условиях.

\section{Список литературы}

[1] Матюшенко А.И., Лютов А.В., Кулагин В.А., Турутин Б.Ф. Теплофизика систем водоснабжения. Красноярск: ИПЦ КГТУ, 2002. 224 с. [Matiushenko A.I. Liutov A.V. Kulagin V.A. Turutin B.F. Thermal physics of water supply systems. Krasnoyarsk: CPI KSTU, 2002. 224 p. (in Russian)].

[2] Турутин Б.Ф., Матюшенко А.И. Термика инфильтрационных сооружений. Красноярск: ИПЦ КГТУ, 2002. 208 с. [Turutin B.F., Matiushenko A.I. Buoyant thermal of infiltration facilities. Krasnoyarsk: CPI KSTU, 2002. 208 p. (in Russian)].

[3] Матюшенко А.И., Кулагин В.А., Турутин Б.Ф. Экология водопользования в криолитозоне. М.: Маджента, 2013. 376 с. [Matyushenko A.I., Kulagin V.A., Turutin B.F. Ecology of water use in the permafrost zone. Moscow: Publishing house «Magenta», 2013. 376 p. (in Russian)].

[4] Матюшенко А.И., Турутин Б.Ф., Лютов А.В. Инженерно-экологические основы систем водоснабжения Сибири и Крайнего Севера. Красноярск: КрасГАСА, 2000. 158 с. [Matyushenko A.I., Turutin B.F., Lyutov A.V. Engineering and ecological foundations of water supply systems in Siberia and the Far North. Krasnoyarsk: KrasGASA, 2000. 158 p. (in Russian)].

[5] Матюшенко А.И., Турутин Б.Ф., Лютов А.В. Комплексное использование водных ресурсов (Восточно-Сибирские регионы); ред. Б.Ф. Турутина. Красноярск: ИПЦ КГТУ, 2003. 300 с. [Matiushenko A.I. Turutin B.F., Liutov A.V. Integrated water resources management (East Siberia); Ed. B.F. Turutin. Krasnoyarsk: CPI KSTU, 2003. 300 p. (in Russian)].

[6] Кулагин В.А., Крючков Г.П. Инженерно-экологическая особенность проектирования водозаборных сооружений Сибирских регионов. Экология урбанизированных территорий, 2007, 3, 65-68. [Kulagin V.A., Kryuchkov G.P. Engineering and environmental feature of the design of water intake facilities of the Siberian region. Ecology of the urbanized territories, 2007, 3, 65-68 (in Russian)].

[7] Кулагин В.А., Крючков Г.П. Природные особенности исследования водозаборов Сибири из подземных источников. Экология урбанизированных территорий, 2007, 3, 52-54. [Kulagin V.A., Kryuchkov G.P. The natural features of studies of Siberia intake from underground sources. Ecology of the urbanized territories, 2007, 3, 52-54 (in Russian)].

[8] Матюшенко А.И., Турутин Б.Ф. Водозаборы подземных вод. Красноярск: КГТУ, 2005. 248 c. [Matyushenko A.I., Turutin B.F. Water intakes of underground waters; Ed. V.A. Kulagin, V.M. Zhuravlev. Krasnoyarsk: KSTU, 2005. 248 p. (in Russian)];

[9] Матюшенко А.И., Турутин Б.Ф., Кулагин В.А. Водоснабжение и водопотребление 2. Красноярска. Красноярск: ИПЦ КГТУ, 2006. 329 с. [Matyushenko A.I., Turutin B.F., Kulagin V.A. Water supply and water consumption in Krasnoyarsk, Krasnoyarsk: IPC KSTU, 2006. 329 p. (in Russia)];

[10] Матюшенко А.И., Кулагина Т.А., Шайхадинов А.А., Тугужаков Д.Б. Повышение эффективности эксплуатации трубопроводов в условиях Сибири и Крайнего Севера. Журнал СФУ. Техника и технологии, 2015, 8(2), 216-226. [Matyushenko A.I., Kulagina T.A., Shaykhadinov A.A., 
Tuguzhakov D.B. Increase of efficiency of operation of pipelines in the conditions of Siberia and the Far North, J. Sib. Fed. Univ. Eng. technol, 2015, 8(2), 216-226. (in Russian)];

[11] Турутин Б.Ф. Проектирование и расчет водозаборных сооружений из подземных источников; ред. В.А. Кулагин, В.М. Журавлев. Красноярск: ИПЦ КГТУ, 2004. 223 с. [Turutin B.F. Design and calculation of water intake facilities from underground sources; Ed. V.A. Kulagin, V.M. Zhuravlev. Krasnoyarsk: CPI KSTU, 2004. 223 p. (in Russian)].

[12] Турутин Б.Ф. Матюшенко А.И., Кулагин В.А. Инженерно-экологическая надежность водоснабжения из подземных источников. Красноярск: ИПЦ КГТУ, РИО КрасГАСА, 2006. 208 c. [Turutin B.F., Matiushenko A.I., Kulagin V.A. Engineering and environmental reliability of the water supply from underground sources. Krasnoyarsk: CPI KSTU, RIO KrasGASA, 2006. 208 p. (in Russian)].

[13] Кулагин В.А., Кулагина Т.А., Матюшенко А.И., Турутин Б.Ф. Физика атмосферы $u$ гидрофизика. Красноярск: ИПЦ КГТУ, 2006. 498 с. [Kulagin V.A., Kulagina T.A., Matiushenko A.I., Turutin B.F. Physics of atmosphere and hydrophysics. Krasnoyarsk: CPI KSTU, 2006. 498 p. (in Russian)]. 